\section{УДК: 616-07+616.89-008}

\section{DOI: 10.26697/ijes.2018.3-4.44}

Психопатологічні прояви ендогенних психозів 3 епізодичним перебігом в станах ремісії/інтермісії

Доцент Хоміцький Микола ${ }^{1}$

${ }^{1}$ Запорізький державний медичний університет, Украӥна

\section{Резюме}

Вступ: Проведення диференційної діагностики ендогенних епізодичних психозів являє собою надзвичайно актуальне завдання сучасної психіатричної теорії і практики з огляду на наявний патоморфоз психічних захворювань та тенденцію останніх років до неухильного розширення i трансформації уявлень про систематику та типологію. Окрім терапевтичних труднощів, дана група психічних розладів в умовах відсутності даних відносно патогенетичних механізмів та параклінічних корелятів, формує диференційнодіагностичну проблематику як у контексті розрізнення із розладами іншого генезу, так i всередині ендогенного кластеру психопатології. Встановлення правильного діагнозу вже на початку ендогенного захворювання $є$ визначним фактором адекватності та успішності подальших терапевтичних та соціально-реабілітаційних заходів, від яких залежить медико-соціальний прогноз та якість життя пацієнтів.

Метою цього дослідження було проведення компаративного аналізу клініко-психопатологічних характеристик (за PANSS) станів ремісії у пацієнтів, які страждають на шизофренію, шизоафективний розлад (ШАР) та афективні розлади (АР).

Методи: На базі Обласної клінічної психіатричної лікарні (м. Запоріжжя) було обстежено 49 пацієнтів (група 1), що страждають на АР (31 пацієнт 3 діагнозом “біполярний афективний розлад” та 183 діагнозом “рекурентний депресивний розлад”), 76 пацієнтів із встановленим діагнозом “шизоафективний розлад” (група 2) та 96 пацієнтів із встановленим діагнозом “параноїдна шизофренія, епізодичний тип перебігу” (група 3). Обов'язковим критерієм включення до вибірки для обох груп був стан клінічної ремісії 3 редукцією психотичної симптоматики. Основними методами дослідження були клініко-катамнестичний та клініко-психопатологічний, а також медико-статистичний аналіз. Результати: Згідно результатам порівняльного аналізу показників виразності психопатологічної симптоматики за PANSS було виявлено достовірні розбіжності між групами порівняння за субшкалами позитивної, негативної та субшкалам загальних розладів ( $<0.01$ з урахуванням поправки Бонферроні). Для субшкали позитивної симптоматики показники для 1-ї, 2-ї та 3-ї груп склали $9.22 \pm 3.03 ; 11.34 \pm 2.96$ та $13.29 \pm 3.11$ балів відповідно. По субшкалі негативної симптоматики показники для 1-ї, 2-ї та 3-ї груп склали 9.46 3.21 ; $12.11 \pm 3.19$ та $17.99 \pm 5.25$ балів. Для субшкали загальних розладів показники для 1-ї, 2-ї та 3-ї груп склали $21.86 \pm 6.88 ; 26.19 \pm 6.76$ та $33.02 \pm 8.32$ балів відповідно.

Загальна тенденція показників за окремими субшкалами та за сумарним показником PANSS (група 3>група 2>група 1) була наявна за більшістю показників загальних розладів $(\mathrm{p}<0.013$ урахуванням поправки Бонферроні), що зазначено нижче. Так, за G5 (Манерність) показники склали $1.37 \pm 0.73 ; 1.75 \pm 0.80 ; 2.31 \pm 0.95$ балів; G7 (Рухова загальмованість): $1.22 \pm 0.65 ; 1.55 \pm 0.70 ; 1.94 \pm 0.90$ балів; за G8 (Відмова від взаємодії (негативізм)): $1.12 \pm 0.62 ; \quad 1.53 \pm 0.70 ; \quad 2.02 \pm 0.88$ балів; G9 (Незвичайний зміст мислення): $1.37 \pm 0.72$; $1.80 \pm 0.75 ; 2.35 \pm 0.83$ балів; за G12 (Порушення критики): $1.69 \pm 0.89 ; 2.68 \pm 0.77 ; 3.25 \pm 1.11$ балів; G13 (Порушення волі): $1.18 \pm 0.63 ; 1.59 \pm 0.70 ; 2.73 \pm 1.12$ балів; та за G15 (Аутизація): $1.18 \pm 0.76 ; 1.71 \pm 0.81$; $2.75 \pm 1.15$ балів відповідно.

За іншими окремими показниками субшкали загальних розладів виявлено такі відмінності. Між групою 1 та групою 3 наявні статистично значущі відмінності $(\mathrm{p}<0.05)$ за G3 (Ідеї провини): $1.18 \pm 0.50$ та $1.35 \pm 0.56$ балів відповідно; G4 (Внутрішнє напруження): $1.45 \pm 0.74$ та $1.79 \pm 0.82$ балів; та за G6 (Депресія) $1.37 \pm 0.65$ та $1.63 \pm 0.70$ балів відповідно. Показник групи 1 за G11 (Дефіцит уваги) був нижчим ( $<0.05)$ за відповідні показники у групах 2 та $3(1.43 \pm 0.77 ; 1.84 \pm 0.78 ; 2.06 \pm 0.92)$, як і за G14 (Зниження контролю над імпульсами (інстинктами)): $(1.37 \pm 0.80 ; 1.76 \pm 0.86 ; 1.71 \pm 0.77)-$ $(\mathrm{p}<0.05)$. Статистично значущі $(\mathrm{p}<0.01)$ відмінності наявні між групами 2 та 3 за G2 (Тривожність): $1.57 \pm 0.74$ та $1.92 \pm 0.82$ балів відповідно.

Отримані результати свідчать про наявність у пацієнтів з періодичними ендогенними психозами в період ремісії стійкої дифузної психопатологічної симптоматики (позитивної, негативної та загальних розладів), виразність якої відрізняється залежно від нозологічної приналежності та зростає у напрямку: афективні розлади - шизоафективний розлад шизофренія. Поліморфізм, стійкість та відносно невисокий рівень (не більше 3 балів за окремими ознаками шкали PANSS) дозволяють кваліфікувати вищезазначені зміни як патоперсонологічні трансформації.

Висновки: Вивчення стійких патоперсонологічних трансформацій зазначених контингентів сприятиме підвищенню точності диференційної діагностики в групі періодичних ендогенних психозів, призводячи до поліпшення ефективності здійснюваних лікувально-реабілітаційних заходів.

\section{Інформація про автора:}

Хоміцький Микола Свгенович - кандидат медичних наук, доцент кафедри психіатрії, психотерапії, загальної та медичної психології, наркології та сексології, Запорізький державний медичний університет, Запоріжжя, Україна.

Наукові інтереси: психіатрія, медична психологія, етологія людини.

Email: nhomitsky@gmail.com 